\title{
The Importance of Technology to the View of the Qur'an for Studying Natural Sciences
}

\author{
Leli $^{1}$, Po Abas Sunarya ${ }^{2}$, Ninda Lutfiani ${ }^{3}$, Nuke Puji Lestari Santoso ${ }^{4}$, Restu Ajeng \\ Toyibah $^{5}$ \\ Universiti Utara Malaysia ${ }^{1}$, University of Raharja ${ }^{2345}$ \\ e-mail: mrs.nirmala@oyagsb.uum.edu.my ${ }^{1}$, abas@raharja.info², ninda@raharia.info ${ }^{3}$ \\ nuke@raharia.info 4 , restu.ajeng@raharia.info 5
}

Mohammed, D., Aini, Q., Supriyanti, D., Sulistiawati, \& Anggraeni, M. (2021). Assimilate The Qur'an's View with Science and Technology Perspectives. Aptisi Transactions on Technopreneurship (ATT), 3(1), 42-47.

DOI: https://doi.org/10.34306/att.v3i1.141

\begin{abstract}
Islam advances its people to spread science and technology. According to Muslims who believe in the Koran, learning to develop science and technology is an attribute of their faith. Those who are knowledgeable have clearly been shown that they will be rewarded invaluable in the last day. Given the current science one can see from an unprecedented investment especially for characteristic, physical and clinical sciences to expand considerable advances in humans. This study aims to examine science and technology from the perspective of the Qur'an, as well as its positive and negative effects on human life. This research is a literature study using a qualitative descriptive approach. The documentary approach is used for data collection, and inductive and deductive inference is used for data analysis. In science that relies on the administration of logical, experimental, or skeptical perceptions for comprehensive and manageable answers to the world's ecological sciences, basic financial and individual problems completely disappear. These early attempts to exploit restless Westerners fit the philosophers' view of reuniting science and the ethics of science from a spiritual worldview. We acknowledge that if scholars, organizational technology, technologists, creative and scientific institutions always pay attention to natural events from positivism, naturalist, modernist, empirical, agnostic or theistic philosophical assumptions describing the various branches from secular to modern science will continue to participate critically. modern cemetery. As assertive individuals, we change the perspective of the real world, nature and life depending on the rules of Tauhid (a statement of the unity of God as Creator, Ruler and Sustainer who undeniably exists). Such world information is the Koran articulated like preferred information in the mainstream world, furthermore, This is an ideal opportunity for sincere researchers and logical sentiment goals, especially young science students and Muslim researchers, to make a change in that world view. so necessary in the investigation of ordinary miracles. We understand that the definite aim for human progress and the state of planetary emergency lies in the reshaping of the Tauhid notion of the Cosmos, Nature and Man as the mystical formation of the normal sciences.
\end{abstract}

Keywords: Technology, Al-Quran, Natural Knowledge.

\section{Introduction}

The Qur'an predicts the application of the Tauhid Faith as a foundation for a Comprehensive and Holistic knowledge of the world. We recognize that researchers, innovation, and logical associations of establishments including colleges see nature and different normal wonders from naturalist, positivist, realist, experimental, innovator, rationalist or agnostic philosophical presupposition which are the principle branches that contrast from the mainstream 
perspective in present reality then current science will keep on being one of the supporters of the grave emergency of present day progress [1]. Along these lines, we uphold the endeavors of non-Muslim researchers or researchers to advance a mystical or supernatural world perspective on the real world, nature and life that depends on the faith in a living and otherworldly Creator and Ruler of such exists [2]. The world perspective on the Koran can be deciphered as: thorough and coordinated originations of life, reality, presence, truth and misrepresentation, communicated by God Almighty in His Last Revelation, the Qur'an, as a basic system of tenet, conviction [3]. Standards, qualities, and standards, as True Guidelines for all people to accomplish the reason they were made [4]. This Guidance is essential to be trailed by all individuals to carry on with a compliant life (Islam) and adjustment to the desire of the Creator, Teacher, Preserver, Living Ruler and Judge of humankind [5].

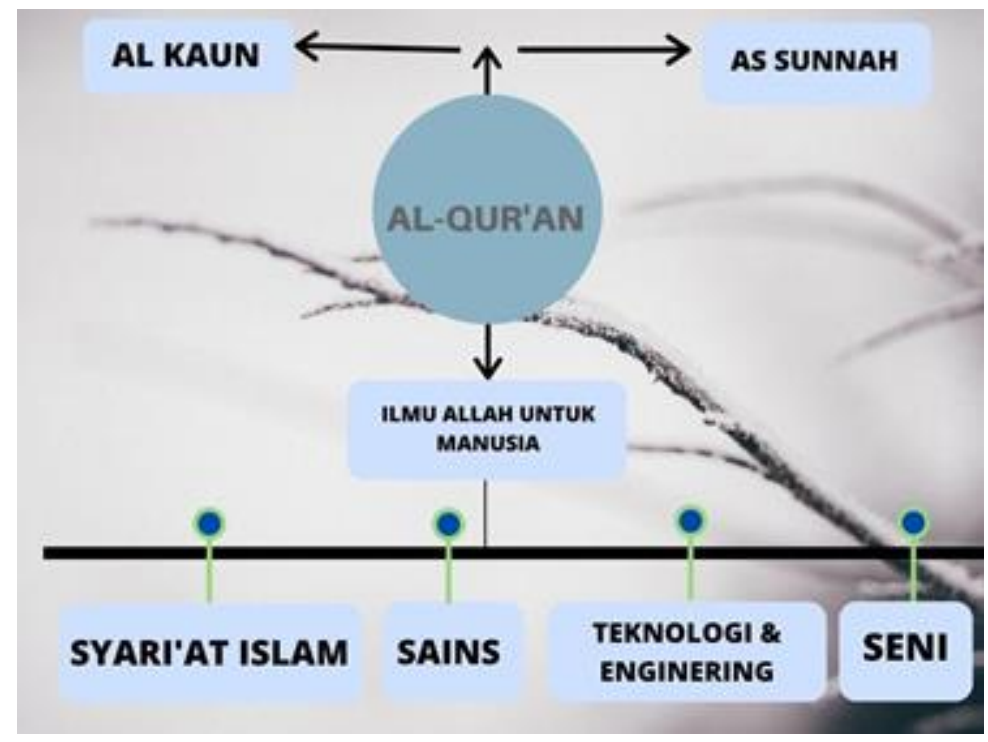

Figure 1. The Koran about science

The perspective of the Qur'an as spoken to in the life and lessons of the Prophet (pbuh) offers the right Guidance, qualities and standards for humanity to pick up the most elevated achievement (al-falāh) and joy and to stay away from definite misfortune (al-khusrān), disappointment and awful enduring in the Immortal Abode in eternity [6]. This is the correct direction for humanity to follow and he anticipates that all slaves should comply. This total guide in the Qur'an and Sunnah is a result of God's Wisdom, not the consequence of wrong human philosophical reasoning or common reasoning [7].

The establishment of this world view is the confidence in the best Truth, to be specific the presence of One God, the Most Gracious, the Most Merciful. This is the conviction and attitude referred to in Islam as the belief of Tawhīd, in avowing the Absolute Oneness of God [8]. With this statement of faith Muslims acknowledge Allah not just as the main Creator or First Cause or Prime Activator or the Supreme yet in addition as the main Object of Adoration, Teacher, Support, Protector, Provider, Ruler, Jury and Source of Supreme Knowledge, shrewdness and worth, for all mankind and such exists [9]. The quintessence of a really monotheistic perspective can be found in the concise declaration of the Islamic confidence (the sentence al-shahādah) that there is no object of love something besides the one True God and that Muhammad is the courier of Allah [10]. The tenet of Tawhid in its complete importance and degree makes it fundamental that every commonplace demonstration or exercises of man must 
not negate his confidence in God and all that is essential and steady worry for His quality since $\mathrm{He}$ is continually viewing, controlling and supporting all issues [11].

The perspectives that make Islam extraordinary and novel from different religions, philosophies or perspectives are the conviction about virtue, supreme and firm Rejection or dismissal of the God's origination of unbelief, and any strict or philosophical convictions that repudiate these convictions Trinitarianism, Polytheism, Pantheism, Deism, Anthropomorphism, humanism, Shamanism, Animism, family line, distortion or love of holy people of people who are dead or living animals that are accepted to have divine forces [12]. Is considered as lie, doubt or avoid. In like manner the world view or bias in Western way of thinking of science, for example, naturalism, skepticism, scientism, physicism, realism, positivism, induction, freethought, mainstream humanism, logic, wariness, existentialism and postmodernism, are completely viewed as types of untruth [13].

Throughout the entire existence of the enormous scope universe of the Qur'an, reality and the plane of presence comprise of two interrelated measurements, the first is the domain of al-ghaib (the concealed world), the domain of presence and the truth which is unimaginable or irrelevant past human reach in this common presence [14]. Recognition, for example, the pith of God, the domain of Divine Commandments, Controls and Decrees, Divine Creation, Divine Intervention, Divine Punishment, Divine Miracles, Spiritual domains. Besides, the Day of Judgment or Judgment Day, Resurrection of body and soul, Eternity, the domain of Angels, the domain of undetectable creatures and the truth of Death [15].

The domain of two presence is 'ālam al-shahādah (the world that can be seen or seen) [16]. It alludes to the issue or actual Cosmos, the universe, the world, nature, people, articles or reality made by Him and can be seen by the faculties and broke down by human explanation, trial and rationale. It is this made universe that is contemplated and broke down by present day common, observational and numerical sciences [17]. We need to understand that, in the investigation of In nature, present day mainstream science disregards if not certainly denies the Single True Creator and Sustainer of the universe, nature and mankind. Rather they appear to enamor nature as the Creative Power and Energy behind everything in presence. Accordingly, nature is considered, examined and seen distinctly as simply actual wonders administered by 'characteristic laws', with no connection to the Creator [18]. This is, from the perspective of the Qur'an, the best learned wrongdoing and foul play (zulm) submitted by the cutting edge mainstream mind. Muslim researchers can't be engaged with this treachery [19].

\subsection{Islamic Opinion on Technological Advancement}

Islam advances its people to spread science and technology, according to Muslims who believe in the Koran, learning to develop science and technology is an attribute of their faith. According to great Islamic intellectuals who are competent in the field of technology. Muslim intellectuals are highly respected and respected by the community, especially when they are given the title Muhandis or can be called brave, intelligent and hardworking people. In Arabic, Muhandis has the same meaning as "Engineer" or "Engineer". Show that technological advances do not create new conditions in the Islamic world. Islam greatly helps the development of its people to conduct experiments and research in any field contained in the field of technology [20]. According to Islam, technology embodies the components of Allah's verses which we must seek the truth and explore. Al-Qur'an as the word of Allah, which was revealed not only for practical purposes. Therefore, the Al-Qur'an as an objective is not an encyclopedia of science and technology, even the Al-Quran does not tell it clearly [21]. 
This development provides relief and serenity for human life as well as forming facilities for human integrity as caliph and servant of Allah. Because Allah has bestowed the gifts of pleasure to humans which are mutually sufficient, namely the enjoyment of technology and religious gifts [22]. One of the implied words of Allah in the Al-quran Surat Ar-Rahman Verse 33, namely:

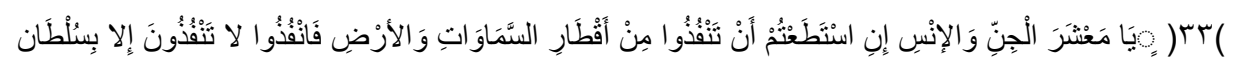

Meaning: "O congregation of jinn and humans, if you are able to penetrate (cross) the corners of heaven and earth, then pass, you cannot penetrate it but with strength." (Surah ArRahman: 33)

\section{Literature Review}

As per Muhammad Asad, an European Islamic researcher eminent in his interpretation and discourse stresses that the Qur'anic emphasis on securing development information among supporters in scholarly interest and free request, has eventually brought about a period of study and logical examination which sees the Islamic world. at the stature of social force and in this way culture was sustained by the Qur'an innumerably and entered into the psyches of middle age Europe and offered ascend to the recovery of Western culture which we call the Renaissance, and hence became throughout time generally answerable for the birth what is portrayed as the "Time of Science": the age wherein we now live [23].

Robert Briffault was prepared as a specialist however later diverted to this examination from the social humanities for which he got acclaimed. His book is a shocker for a Western public who gets Islam and its development dependent on misconception, contortion, falsehood and bias [24]. Robert Briffault is insistent in mentioning that advanced European human progress owes its beginnings to the impact of the Islamic culture which created characteristic science and advanced a logical soul: Modern European development couldn't have ever emerged at all it was exceptionally sure yet to them it would not have been. expect such a character that permits him to rise above all past periods of advancement [25]. For despite the fact that there is certainly not a solitary part of European development where the impact of Islam so decides culture can't be followed, there isn't anything so evident and significant as in the inception of that power which is the most significant separating power of the advanced world and the incomparable wellspring of the victory of normal science and science. logical soul. Europe's obligation to Arab culture isn't just in logical revelations: the presence of European science was made reasonable to Arab (Islamic) culture on the grounds that the Arabs presented new strategies for examination, 'techniques for experimentation, perception, estimation, improvement of numerical opment in a structure obscure to them. the Greeks [26].

Our obligation to the Arabs of science doesn't comprise of astonishing revelations or disclosures. Science owes more to Arab culture, it owes its reality. It was the old world, as should be obvious, pre-logical. Greek space science and arithmetic were imported products never completely adjusted in Greek culture [27]. The Greeks were precise, general and guessed, yet a method of patient request, aggregation of positive information, little techniques for science, itemized and delayed perception, test examination, totally unfamiliar to the Greek personality What we call science arose in Europe because of another soul of request. , another strategy for speculation tigation, from the technique for experimentation, perception, estimation, to numerical advancements in a structure obscure to the Greeks. That soul and the technique was acquainted with the European world by the Arabs [28]. 
Briffault clarifies that albeit Muslim researchers acquired Greek work, their techniques varied from those of the Greeks. In the wake of portraying the exact work of the Muslim Scientist, Briffault calls upon his perusers to 'separate the logical soul of constancy and diligence in perception from the theoretical strategy for prior [the Greeks] which disparage simple induction; with Aristotle proceeding to compose material science without directing a solitary test. Briffault uncovers that both and later European researchers presented the trial technique: 'Roger Bacon was simply a witness of Muslim Science and Methods to Christian Europe; and he never burnt out on Ried expressing that information on Arabic and Arabic science was peers for the best way to genuine information. Briffault states that the act of considering Europeans as the source of logical disclosures and revelations is' important for an enormous confusion about the birthplaces of European Civilization. He presumed that 'Science is the main commitment of Arab human advancement to the cutting edge world [29].

\section{Method}

In this study, researchers used a qualitative analysis approach that was more focused on library research. Studies that focus on the analysis or interpretation of written content are known as literature or text reviews. To achieve high credibility in this literature review, the author uses the verses of the Koran that are relevant to science and technology as the primary source (primary), while the source of supporting data (secondary) is thought [30]. someone mentioned in a book or published manuscript that is relevant to the discussion of the subject. Logical exploration with political, military, and corporate whip foundations keeps on putting stock in science's conventional mental self view of isolated virtue. The idea of "unadulterated science" is presently scrutinized by numerous individuals as totally deceptive. That conviction has the logical psyche novel admittance to the facts of the world, that it can enlist nature as an ideal mirror mirroring a target reality that is extra-recorded and widespread, seen as epistemologically gullible, yet in addition as serving, if intentionally [31].

Explicit political and monetary plans frequently consider broad knowledge and assets to be directed for social and environmental control programs. The forceful misuse of the common habitat, the expansion of atomic weapons, the worldwide danger of fiasco all prompting the charge of science, human explanation itself, presently appears to depend on man own reckless madness.

It has gotten clear to numerous discerning and self-basic masterminds in the West that the present development all in all is in harm's way [32]. 18 Tarnas closes top to bottom a declaration of frustration with the negative moral and environmental outcomes of the absence of an ethical compass in the logical and mechanical improvements of contemporary progress: 'The West has again lost its confidence, this time isn't in religion however in science and in the psyche of self-ruling people's.

\section{Results And Discussion}

The incomparable authority of Divine Revelation as the wellspring of preeminent information was recently underlined. The idea of information (or science, as al-'ilm implies both information and science) in the Qur'an places the most elevated an incentive on knowing God (ma'rifat Allah) as the most significant standard for every person. This, along with information on man's actual relationship (al-clamor) with God, is the most elevated information and science in the chain of importance of information in the perspective of the Qur'an. Information and the study of life on the planet (al-dunyā) is another classification of information, however it isn't to be isolated or isolated from the study of al-dīn (all encompassing Islamic life exchanges) [33]. It 
is hence that Muslim researchers comprehend two significant classifications of information and science: the first is called 'uncovered (or sent, naqliy information, which has unceasing worth, and the second' gained (or intel-lectamah, aqliy) information which has worldly worth. Gian Classical Muslim religious philosophy, the most unmistakable of which is al-Imam al-Ghazali (1058-1111), has ordered the principal classification of information and science as' required for the individual (farynAyn) for all Muslims. The subsequent class, which can't be isolated from the principal classification, considered 'mandatory for the network in general (fard kifāyah). The Koran unmistakably cautions against the impact of irrational theory or guess (zann) in human idea, the negative defilement of human explanation feelings or thoughts and perspectives of human autonomy and presumption (takabbur). It reminds man that, without brightening and direction From Divine disclosure, all human explanation realizes best is outside the common life structure ya 'lamūna zāhiran min al-hayāt al-dunyā. All things being equal, the fringe information that God gave people "is just a bit." Thus, the present astounding wealth of logical information, innovativeness, and mechanical advancement ought not prompt shrewd individuals, including researchers, for example, theo-expository theo-physicist Stephen Hawking (creator of A Brief History of Time [1988] and The Grand Design [2010]) and Michio Kaku (Physics of the Future [2011]) to think or think about mainstream science, without the assistance of God's religion or a solid way of thinking phy, can address all inquiries regarding the beginning and nature of the universe [34].

From the investigation of the Qur'anic stanzas about normal marvels, we can find the fundamental standards with respect to the idea of the regular request. Past the point of no return Professor Ismai 'il Raji al Faruqi (1986), in his celebrated book The Cultural Atlas of Islam, examines these five standards in a philosophical style [35].

1. Creation - Nature was made by One True God.

2. Fleetingness - Nature is a common and common element, not heavenly.

3. Request - Nature is deliberate, adjusted and wonderful and capacities as indicated by the laws of One True God.

4. Reason - Nature was made for a reason by God Almighty.

5. Acquiescence - Nature was made to submit to and submit to human requirements.

The Qur'an orders over and over that the entirety of God's endowments must be thought of, covered, broke down and utilized by humanity utilizing natural detects, knowledge, reason and exact methods [36]. The comprehensive methodology requested by the Koran, specifically the investigation of nature based on confidence in God Almighty and a disposition of consciousness of God is spoken to by 'Ulama' (researchers who dread God) and the model of Ūlū al-Albāb examined previously [37]. Logical, levelheaded and observational investigations of normal wonders are conceivable due to the dependability, consistency, routineness, steady circumstances and logical results connections, and consistency presented by God Almighty in the actual universe [38].

\section{Conclusions And Suggestions}

The finish of this article is that skeptic researchers, naturalists and nonbelievers likewise have their own originations of reasoning dependent on their particular perspectives. By and by, the college's vision Combines the humanistic parts of human idea with observational methods for regard - deciphered on the grounds that it means a powerful urge to move from a simply materialistic or logical perspective that is in opposition to strict (counting Islamic) world perspectives. For Muslims, the perspective of the Qur'an is promptly accessible for nature and 
social researchers to build 'another structure of information', which consolidates theory and science, and this perspective has created a splendid human progress before the ascent of present day Western common development. One of the fundamental snags to the suggestion that there is a significant move from a common information worldview to a comprehensive information worldview is the thing that Wallerstein recognizes as the 'pride of man' soul of mainstream progress.

We at that point note that the new world request imagined by this basic mastermind will create new information structures in view of the genuine lacks of the current common information worldview. In the development of new information at this edge, theory and science will not, at this point be separated and the epistemology of coordinated information will be reconstructed. Such a dream adjusts to what the perspective of the Qur'an envisions, however we question that the way of thinking he has will be like the way of thinking of the Qur'an, to be specific the way of thinking of the 'Ulama' who dread God and Ülū al-Albāb of human pride has become the best human restriction. This, it appears to me, is the message of the Adam story in the Garden of Eden. We [Western scholars] are glad in professing to have gotten and understanding God's disclosures. We are considerably more pleased in asserting that we are fit for achieving unceasing truth using human explanation, being some unacceptable methods. Furthermore, we are consistently haughty in attempting to force each other, and with such viciousness and brutality, our emotional portrayals of an ideal society.

In our view, it requires a feeling of quietude, not exclusively to understand the grave slip-ups of present day mainstream human advancement however to examine and comprehend the universe and general wonders in an all encompassing way. This soul, we give up, can just develop from our acknowledgment of the constraints of human explanation when contrasted with the restrictions of the idea of Divine Wisdom; our ability to recognize our real essence as Servants of the One True God; our duty as Representatives on His earth who utilize all the blessings and arrangements given by God as per the desire of the Creator; our comprehension of nature as a Divine Property and a Divine Sign to be drawn nearer with the fitting admiration and appreciation; from our dealings with nature as a type of practicing the Trust that God has set on our shoulders; and our investigation of normal marvels as a type of knowing and loving a Compassionate Creator.

We expectation and expectation that Muslim understudies of regular science and innovation will be another age of researchers - another age of 'ulama' and Ūlū al-Albāb - who start their investigation of characteristic science from the perspective of the Qur'an. The logical information about nature and the Cosmos as Properties, Kingdoms and Signs of God Almighty that they get from this magical and profound viewpoint isn't just to use normal assets for the actual advantage of human government assistance and progress. Its higher point is eventually to make individuals and society know God by realizing His signs, among which are His quality, plan and reason; His endowments and gifts; The laws are in nature, people and society; Intelligence, information and shrewdness; Sovereignty and administration; Love, empathy and benevolence; and His craft, equilibrium and excellence. This information then about the actual universe (al-kawn) comes from exact perception, explore, numerical investigation and scrutinizing thinking, including the orders of material science, science, science, stargazing, and so on, along with the determined information on strict truth. (al-racket), including the controls of Islamic Theology ('ilm al-tawhīd), strict love ('ilm al- ibādah), social monetary exchanges ('ilm al-mu amalāt), moral conduct and otherworldliness ('ilmal-akhlāq), making life and works of Muslims as an exhaustive love ('ibādah) God the Most Gracious. 


\section{Acknowledgments}

For resolving this scientific work, the author would like to express his deepest gratitude to the aspects that have provided support to the author in this study and also to the mentors who have provided direction and guidance during the writing of this paper.

\section{References}

[1] U. Rahardja, Q. Aini, and A. Khoirunisa, "The Effect of Rinfogroups as a Discussion Media in Student Learning Motivation," Aptisi Trans. Manag., vol. 2, no. 1, pp. 79-88, 2018.

[2] P. A. Sunarya, U. Rahardja, L. Sunarya, and M. Hardini, "The Role Of Blockchain As A Security Support For Student Profiles In Technology Education Systems," InfoTekJar J. Nas. Inform. dan Teknol. Jar., vol. 4, no. 2, pp. 13-17, 2020.

[3] U. Rahardja, Q. Aini, and A. Khoirunisa, "Effect of iDu (iLearning Education) on Lecturer Performance in the Lecture Process," Aptisi Trans. Manag., vol. 2, no. 2, pp. 140-148, 2018.

[4] U. Rahardja, T. Hariguna, and Q. Aini, "Understanding the Impact of Determinants in Game Learning Acceptance: An Empirical Study.," Int. J. Educ. Pract., vol. 7, no. 3, pp. 136-145, 2019.

[5] U. Rahardja, N. Lutfiani, and H. L. Juniar, "Scientific Publication Management Transformation In Disruption Era," Aptisi Trans. Manag., vol. 3, no. 2 July, pp. 109-118, 2019.

[6] U. Raharja, N. Lutfiani, I. Handayani, and F. M. Suryaman, "Motivasi Belajar Mahasiswa Terhadap Metode Pembelajaran Online iLearning+ Pada Perguruan Tinggi," SISFOTENIKA, vol. 9, no. 2, pp. 192-202, 2019.

[7] U. Rahardja, N. Lutfiani, E. P. Harahap, and L. Wijayanti, "iLearning: Metode Pembelajaran Inovatif di Era Education 4.0," Technomedia J, vol. 4, no. 2, pp. 261-276, 2021.

[8] U. Rahardja, A. Moein, and N. Lutfiani, "Leadership, competency, working motivation and performance of high private education lecturer with institution accreditation B: Area kopertis IV Banten province," Man India, vol. 97, no. 24, pp. 179-192, 2018.

[9] U. Rahardja, E. P. Harahap, and S. R. Dewi, "The strategy of enhancing article citation and $\mathrm{H}$-index on SINTA to improve tertiary reputation," TELKOMNIKA, vol. 17, no. 2, pp. 683-692, 2019.

[10] J. Hom, B. Anong, K. B. Rii, L. K. Choi, and K. Zelina, "The Octave Allegro Method in Risk Management Assessment of Educational Institutions," Aptisi Trans. Technopreneursh., vol. 2, no. 2, pp. 167-179, 2020.

[11] S. Santoso, J. Kauf, and N. C. Aristo, "The Information System of Name Card Sales Based on Digital Marketing to Improve Creativepreneur on College E-Commerce Website," Aptisi Trans. Technopreneursh., vol. 1, no. 1, pp. 64-72, 2019.

[12] I. Handayani, E. Febriyanto, and A. Jethro, "Designing Popular Classes on Viewboard Public Assessment of Lectures Based on YII Framework," Aptisi Trans. Technopreneursh., vol. 1, no. 2, pp. 144-156, 2019.

[13] T. Nurhaeni, K. W. Karts, and M. Hardini, "Viewboard Effectiveness on Raharja Internet Cafe Website as Sales Information Submission Media," Aptisi Trans. Technopreneursh., vol. 1, no. 1, pp. 20-26, 2019.

[14] A. B. Wandanaya and D. Rahmasary, "The Impact Analysis Of Stock Reminder Of Goods To Quality Company," Aptisi Trans. Manag., vol. 3, no. 2, pp. 142-148, 2019.

[15] M. Yusup, R. S. Naufal, and M. Hardini, "Management of Utilizing Data Analysis and Hypothesis Testing in Improving the Quality of Research Reports," Aptisi Trans. Manag., vol. 2, no. 2, pp. 159-167, 2018.

[16] E. S. N. Aisyah and O. Y. Keat, "Utilization of Online Accounting Software As A Supplier Data Collection System At The Company," Aptisi Trans. Manag., vol. 1, no. 2, pp. 8085, 2017. 
[17] H. Henderi, S. R. Zuliana, and R. A. Pradana, "Periodic Data Analysis and Forecasting As An Overview of Future Management Economics," Aptisi Trans. Manag., vol. 3, no. 1, pp. 73-83, 2019.

[18] W. G. W. Wardani, "DRIVE CAMPAIGNS:" ANTI-SHARING IMAGES/PHOTOGRAPHS HARASSING WOMEN ON INSTANT MESSAGING APPS PHONE VISITING," ADI J. Recent Innov., vol. 2, no. 1, pp. 82-89, 2020.

[19] W. Andriyan and V. Anesti, "Visual Audio Communication Design on the Role of Information Technology on Student Life Style of Universitas Raharja," ADI J. Recent Innov., vol. 2, no. 1, pp. 15-24, 2020.

[20] S. Sutirna, "Total Quality Management Through Lecturer Assessment With Students to Improve Graduate Quality," ADI J. Recent Innov., vol. 2, no. 1, pp. 51-65, 2020.

[21] N. F. Rozy, R. Ramadhiansya, P. A. Sunarya, and U. Rahardja, "Performance Comparison Routing Protocol AODV, DSDV, and AOMDV with Video Streaming In Manet," in 2019 7th International Conference on Cyber and IT Service Management (CITSM), 2019, vol. 7, pp. 1-6.

[22] T. Alam, "Cloud Computing and its role in the Information Technology," Tanweer Alam.(2020). Cloud Comput. its role Inf. Technol. IAIC Trans. Sustain. Digit. Innov., vol. 1, no. 2, pp. 108-115, 2020.

[23] H. T. Sukmana, "Prototyping ITSDI Journal Center Menggunakan Tools Invision Untuk Mewujudkan Creative Innovation Soft Skill Di Era Industri 4.0," ADI Bisnis Digit. Interdisiplin J., vol. 1, no. 1, pp. 56-69, 2020.

[24] K. Kholil, K. Sulistyadi, and S. Arlan, "Strategies of Food Safety Program Improvement to Prevent Food Poisioning Outbreak At Oil \& Gas Industrial City," ADI J. Recent Innov., vol. 1 , no. 1 , pp. $46-53,2019$.

[25] A. Alwiyah and S. Sayyida, "Penerapan E-Learning untuk Meningkatkan Inovasi Creativepreneur Mahasiswa," ADI Bisnis Digit. Interdisiplin J., vol. 1, no. 1, pp. 35-40, 2020.

[26] I. Handayani, U. Rahardja, E. Febriyanto, H. Yulius, and Q. Aini, "Longer Time Frame Concept for Foreign Exchange Trading Indicator using Matrix Correlation Technique," in 2019 Fourth International Conference on Informatics and Computing (ICIC), 2019, pp. $1-5$.

[27] C. P. Latha and M. Priya, "A review on deep learning algorithms for speech and facial emotion recognition," APTIKOM J. Comput. Sci. Inf. Technol., vol. 1, no. 3, pp. 92-108, 2016.

[28] M. Kamil, J. Rianto, and D. Suprayogi, "Management of Deciding Decision Making Final Project Advisor in Optimizing Learning," Aptisi Trans. Manag., vol. 2, no. 2, pp. 168-176, 2019.

[29] M. S. Shaik, K. S. Prasad, R. A. Shaik, and D. V. Rao, "Acoustic Echo Cancellation using Computationally Efficient Adaptive Algorithm Techniques," Aptikom J. Comput. Sci. Inf. Technol., vol. 1, no. 2, pp. 57-62, 2016.

[30] Q. A. Henderi, N. P. L. Santoso, A. Faturahman, and U. Rahardja, "A proposed gamification framework for smart attendance system using rule base," J. Adv. Res. Dyn. Control Syst, vol. 12, no. 2, pp. 1827-1838, 2020.

[31] D. Andayani, N. P. L. Santoso, A. Khoirunisa, and K. Pangaribuan, "Implementation of the YII Framework-Based Job Training Assessment System," Aptisi Trans. Manag., vol. 5, no. 1, pp. 1-10, 2021.

[32] U. Rahardja, I. Handayani, N. Lutfiani, and F. P. Oganda, "An Interactive Content Media on Information System iLearning+," IJCCS (Indonesian J. Comput. Cybern. Syst., vol. 14, no. 1, pp. 57-68, 2020.

[33] S. Sudaryono, Q. Aini, N. Lutfiani, F. Hanafi, and U. Rahardja, "Application of Blockchain Technology for iLearning Student Assessment," IJCCS (Indonesian J. Comput. Cybern. Syst., vol. 14, no. 2, pp. 209-218.

[34] M. A. Mumen, F. P. Oganda, N. Lutfiani, and I. Handayani, "Implementation of OJS Based iJC Media E-Journal System at University of Pramita Indonesia," Aptisi Trans. Manag., vol. 4, no. 2, pp. 168-177, 2020.

[35] Q. Aini, M. Budiarto, P. O. H. Putra, and N. P. L. Santoso, "Gamification-based The 
Kampus Merdeka Learning in 4.0 era," IJCCS (Indonesian J. Comput. Cybern. Syst., vol. 15, no. 1, pp. 31-42.

[36] M. Herlina, U. S. Sa'ud, D. Disman, W. Sopandi, and N. P. L. Santoso, "Pengembangan dan Kesiapterapan Jiwa Kewirausahaan pada Siswa Sekolah Dasar," J. Pemikir. dan Pengemb. Sekol. Dasar, vol. 8, no. 2, pp. 96-106, 2020.

[37] S. Sudaryono, N. P. Lestari, and K. Gunawan, "PERANCANGAN VIRTUAL ASSISTANT ENTREPRENEURSHIP MENGGUNAKAN METODE SCRUM," J. Innov. Futur. Technol., vol. 2, no. 2, pp. 66-77, 2020.

[38] Q. Aini, U. Rahardja, N. P. L. Santoso, and A. Oktariyani, "Aplikasi Berbasis Blockchain dalam Dunia Pendidikan dengan Metode Systematics Review," CESS (Journal Comput. Eng. Syst. Sci., vol. 6, no. 1, pp. 58-66. 